\title{
Pengaruh Harga dan Inovasi Layanan Aplikasi terhadap Keputusan Penggunaan Jasa Taksi Express: Survei pada Pengunduh Aplikasi Express Taxis
}

\author{
Reminta Lumban Batu ${ }^{1)}$, Nine Inten Suryani ${ }^{2)}$, Nita Septia ${ }^{3)}$, \\ Priska Febiola Sekaryahya ${ }^{4)}$ \\ 1), 2), 3), 4) Universitas Singaperbangsa Karawang \\ reminta.lumban@fe.unsika.ac.id ${ }^{1)}$,nine.intan17162@student.unsika.ac.id²), \\ nita.septia17163student.unsika.ac.id ${ }^{3)}$,priska.febiola17174@student.unsika.ac.id ${ }^{4)}$
}

\begin{abstract}
Abstrak
Penelitian ini bertujuan untuk menginvestigasi pengaruh harga dan inovasi layanan aplikasi terhadap keputusan penggunaan jasa Taksi Express. Penelitian ini mengumpulkan data primer berupa kuesioner dari 176 responden dan data sekunder berupa pengunduh aplikasi Express Taxis pada Playstore sejumlah 500 pengunduh sebagai sampel penelitian. Teknik sampling penelitian ini adalah teknik non-probability sampling dengan teknik sampling purposive menggunakan rumus Isaac dan Michael. Penelitian ini melakukan verifikasi model penelitian dengan Partial Least Square (PLS). Dari hasil analisis menunjukkan bahwa harga dan inovasi layanan aplikasi memiliki pengaruh yang signifikan terhadap variabel keputusan penggunaan jasa. Hasil penelitian ini memperkaya literatur tentang layanan taksi online. Selain itu, hasil penelitian ini juga bermanfaat bagi para manajer jasa taksi online untuk mempertimbangkan harga dan inovasi layanan untuk dapat menarik minat pelanggan.
\end{abstract}

Kata Kunci: harga, inovasi layanan, taksi online

\section{Pendahuluan}

Dewasa ini, persaingan dalam dunia bisnis yang saat ini semakin ketat membuat perusahaan saling bersaing dalam menawarkan keunggulan produknya masing-masing. Sementara itu konsumen semakin selektif dalam memilih suatu barang atau jasa yang mereka butuhkan. Oleh karena itu perlu diterapkan strategi pemasaran yang efektif dan efisien oleh perusahaan agar dapat memenuhi kebutuhan konsumen dan produknya mampu bersaing dengan para pesaingnya. Suatu perusahaan yang menjalankan fungsinya apabila mampu menjual produknya pada konsumen dan memperoleh profit semaksimal mungkin dikatakan berhasil.

Sebagai sarana yang sangat penting, jasa transportasi saat ini dirasa sebagai sarana yang sangat penting di dalam kehidupan masyarakat, transportasi digunakan setiap masyarakat untuk memperlancar aktivitas sehari-harinya, setiap orang tentu membutuhkan transportasi dalam berbagai kegiatannya seperti bekerja, bepergian maupun aktivitas lainnya (Maroun et al, 2016). Banyaknya pilihan transportasi umum seperti bis, kereta, angkot, dan taksi yang tersedia apabila tidak menggunakan kendaraan pribadi. Di antara pilihan itu semua, tentu setiap orang memiliki pilihannya masing-masing sesuai dengan kebutuhan, angkutan taksi adalah transportasi yang menawarkan kenyamanan paling tinggi. Taksi adalah pilihan yang lebih nyaman karena tidak perlu berdesakkan dengan orang lain, bebas panas ataupun hujan, serta tidak perlu berganti angkutan lain untuk sampai ke tempat tujuan yang tidak bisa dijangkau kendaraan umum lainnya. Taksi juga menjadi pilihan karena tidak membuang waktu seperti kendaraan umum lainnya, taksi tidak "ngetem" untuk menunggu penumpang lain, juga tidak perlu ke lokasi 
khusus (seperti halte/stasiun) untuk didapatkan. Taksi dinilai lebih aman dari kendaraan umum lainnya sehingga menjadi pilihan yang eksklusif. Kita dapat melihat identitas supir secara jelas di kartu pengenal yang tertera pada dashboard di kursi penumpang depan serta dapat mencatat nomor kode taksi (Erwin, 2016).

Keadaan taxi konvensional sedang dalam masa yang tidak baik saat ini. Dari 32 penyedia taxi konvensional yang ada, hanya tersisa lima perusahaan yang masih bertahan hingga saat ini yaitu Blue Bird, Express, Taxiku, Basowa, dan Cipaganti. Terbukti dengan konsistensi taksi Express menjadi “TOP BRAND” dari tahun 2015 sampai 2019 Top Brand Award dalam kategori taksi. Namun Taksi Express belum dapat mengganti posisi kompetitornya yaitu Taksi Blue Bird yang selalu menempati posisi pertama Top Brand Award.

Table 1. Top brand award kategori taksi (2017-2019)

\begin{tabular}{|c|c|c|c|c|c|c|c|c|}
\hline \multicolumn{2}{|c|}{2017} & \multicolumn{3}{c|}{2018} & \multicolumn{3}{c|}{2019} \\
\hline Merek & TBI & TOP & Merek & TBI & TOP & Merek & TBI & TOP \\
\hline Blue Bird & $57,3 \%$ & TOP & Blue Bird & $58,6 \%$ & TOP & Blue Bird & $53,1 \%$ & TOP \\
\hline Express & $12,9 \%$ & TOP & Express & $13,0 \%$ & TOP & Express & $10,5 \%$ & TOP \\
\hline Taxiku & $6,4 \%$ & & Taxiku & $5,7 \%$ & & Taxiku & $7,9 \%$ & \\
\hline Bosowa & $4,5 \%$ & & Bosowa & $5,5 \%$ & & Bosowa & $7,8 \%$ & \\
\hline Gemah Ripah & $1,9 \%$ & & Cipaganti & $4,0 \%$ & & Cipaganti & $4,6 \%$ & \\
\hline
\end{tabular}

Sumber: https://www.topbrand-award.com

Dari tahun 2017 dan 2019 dalam kategori taksi , taksi Express berada di posisi kedua dan berhasil meraih penghargaan Top Brand Indonesia. Taksi Express berada di posisi kedua dengan nilai TBI 12,9\% pada 2017 dan 13,0\% pada 2018 dan 10,5\% pada 2019. Meskipun jauh dengan kompetitornya taksi Blue Bird yang selalu mendapat TBI diatas 50\%, taksi Express tetap merupakan pesaing yang paling diperhitungkan dalam industri angkutan taksi. (https://www.topbrand-award.com, diakses pada Tanggal 14 Oktober 2019, Pk 15.54 WIB).

Keunggulan strategi taksi Express dalam menjalankan bisnisnya adalah dengan memberikan tarif lebih murah dari kompetitor. Hal tersebut yang selama ini dirasakan masyarakat sehingga banyak memilih taksi Express sebagai pilihan. Saat ini taksi Express sudah mengikuti peraturan baru yang ditentukan oleh organda, yaitu Rp 6.500 tarif buka pintu, Rp 3.500 per kilometer, dan Rp 42.000 tarif tunggu per jamnya. Penyesuaian kebijakan ini merupakan tanggapan pemerintah dari aksi mogok kerja dan demo para supir taksi di Jakarta 22 Maret 2016 lalu. Kebijakan ini tidak menguntungkan pihak taksi Express karena memaksa para kompetitor menyamai tarif mereka, sehingga tidak ada lagi perbedaan tarif pada taksi regular (Rizan, Fadillah, \& Kresnamurti R. P., 2015).

Penurunan pendapatan taksi Express juga terjadi masalah. Pada tahun 2016 tercatat pendapatan usaha menunjukkan penurunan yang cukup besar hingga 2018 taksi Express terus terjadi penurunan pendapatan Berkurangnya pendapatan dan meruginya taksi Express pada tahun 2018 ini mengindikasikan bahwa pelanggan taksi Express mulai menurun dan ini menunjukkan 
berkurangnya minat pelanggan terhadap keputusan penggunaan jasa taksi Express.

Menurut Sugianto, PT Express Transindo Utama Tbk yang merupakan salah satu contoh dari perusahaan taxi konvensional, yang telah melakukan pemutusan hubungan kerja (PHK) terhadap kurang lebih 250 karyawan per Juni 2017 dan memiliki rencana untuk menjual asset berupa tanah dan ruko serta beberapa unit armada untuk mengurangi kewajiban atau membayar hutang jangka panjang perseroan. Hal tersebut dilakukan juga untuk menunjang operasional PT Express Transindo Utama Tbk. Diakui juga bahwa menurunnya utulitas armada taksi yang beralih ke transportasi berbasis aplikasi atau online yang mengakibatkan hal ini terjadi. (https://finance.detik.com, diakses pada Tanggal 14 Oktober 2019, Pk 17.37 WIB).

Table 2. Jumlah pendapatan Taksi Express 2016-2019

\begin{tabular}{|c|c|c|}
\hline Tahun & Jumlah Pendapatan dalam Milyar & Presentase Penurunan Pendapatan \\
\hline 2016 & 618,207 & \\
\hline 2017 & 304,711 & $50,71 \%$ \\
\hline 2018 & 241,663 & $20,69 \%$ \\
\hline
\end{tabular}

Masalah penurunan pelanggan terhadap keputusan penggunaan jasa taksi express merupakan cerminan dari menurunnya kepuasan pelanggan taksi express. Hal ini diperkuat oleh beberapa pelanggan yang menyatakan tidak ingin lagi menggunakan jasa taksi Express. Seperti yang dimuat dalam situs viva.co.id yang menyampaikan bahwa salah satu penumpang kecewa dengan taksi Express yang selama ini diagungkan olehnya. Hal ini dikarenakan penumpang tertidur dalam perjalanan dan dibawa keliling-keliling hingga argo yang ditagihkan sangat mahal. Faktor tarif yang dirasa sangat tinggi ini mengurangi niat pelanggan untuk menggunakan ulang jasa yang disediakan, yang berarti berpengaruh terhadap keputusan penggunaan jasa Taksi Express (https://www.viva.co.id/, diakses pada tanggal 14 oktober 2019, Pk 18.06).

Dalam satu dekade terakhir muncul fenomena perkembangan teknologi yang diintegrasikan dengan transportasi. Melalui ponsel, konsumen dapat dimudahkan dalam mengakses berbagai teknologi yang digunakan dalam transportasi. Kondisi ini menciptakan pengembangan aplikasi transportasi berbasis online pada beberapa perusahaan. Perkembangan teknologi membuat konsumen menganggap bahwa transportasi publik menjadi lebih efisien dari segi akses dan biaya. Selain itu, efisiensi juga didapat oleh konsumen dari segi pemesanan yang dapat dilakukan secara cepat dan real time sehingga konsumen dapat melakukan mobilisasi kemanapun dengan aplikasi tersebut. Fenomena tersebut menyebabkan adanya peralihan pengguna taksi konvensional ke transportasi online. Kehadiran transportasi-transportasi online yang sudah merajalela berdampak pada Keberadaan taksi Express yang telah ada sejak lama ini. (Marsada, 2014). Semakin pesatnya pertumbuhan dalam konsumsi media transportasi jasa berupa taksi yang saat ini sudah menggunakan aplikasi online, seperti GrabCar dan Uber, dari kedua jasa taksi online tersebut yaitu GrabCar dan Uber merebut pangsa pasar dari perusahaan taksi konvensional (Motors \& Europe, 2016).

Dengan adanya jasa transportasi berbasis aplikasi online yang masuk di Indonesia perusahaan jasa transportasi konvensional harus mempunyai strategi agar dapat bersaing sehat dengan 
perusahaan jasa transportasi berbasis aplikasi online. Perusahaan jasa transportasi konvensional belum siap menghadapi persaingan dengan transportasi berbasis aplikasi online dan pengembangan aspek pemasaran jasa transportasi kendaraan konvensional yang belum efektif dalam menghadapi persaingan jasa transportasi kendaraan berbasis aplikasi online.(Motors \& Europe, 2016).

Berdasarkan uraian di atas dapat disimpulkan bahwa ada penyusutan armada transportasi darat yaitu taksi konvensional yang awalnya berjumlah 32 penyedia jasa menjadi 5 yaitu Blue Bird, Express, Taxiku, Basowa, dan Cipaganti. Penyusutan tersebut terjadi karena adanya kompetitor baru yaitu transportasi berbasis online yang memudahkan konsumen

Tarif Taksi Express yang selama ini dikenal lebih murah tidak lagi menjadi senjata utama, hal ini menurunkan kepuasan pelanggan karena sekarang semua tarif seluruh taksi regular telah disamakan oleh organda, yang berakibat mengurangi minat konsumen. Terjadinya penurunan presentase pendapatan taxi express sebesar 50,71\% pada tahun 2016-2017, sedangkan pada tahun 2017-2018 terjadi penurunan pendapatan sebesar 20,69\%. Hal ini menyebabkan PT. Express Transindo Utama Tbk melakukan pemutusan hubungan kerja (PHK) terhadap karyawannya sebesar kurang lebih 250 karyawan pada tahun 2017.

PT. Express Trasindo Utama Tbk dianggap lamban dalam berinovasi memenuhi kebutuhan konsumen sehingga bermunculan taksi online yang lebih memudahkan konsumen. Transportasi umum berbasis aplikasi semakin di gemari masyarakat dunia termasuk di Indonesia sehingga pengguna jasa Taksi Express mengalami penurunan sejak dihadirkannya taksi berbasis aplikasi online. Fasilitas yang diberikan oleh pesaing lebih menarik minat pengguna jasa sehingga menjadi faktor yang dapat memengaruhi keputusan penggunaan Jasa Transportasi Taksi Express.

Berdasarkan informasi di atas, penelitian ini merumuskan masalah penelitian sebagai berikut: (1) Seberapa besar pengaruh harga terhadap keputusan penggunaan jasa di PT. Express Transindo? (2) Seberapa besar pengaruh inovasi layanan aplikasi terhadap keputusan penggunaan jasa? (3) Seberapa besar pengaruh harga dan inovasi layanan aplikasi terhadap keputusan penggunaan jasa di PT. Express Transindo? Penelitian ini memberikan beberapa kontribusi terhadap literatur taksi online dengan menggunakan variabel harga dan inovasi layanan pada Express Taxis. Selain itu, secara praktis, hasil analisis pengaruh harga dan inovasi layanan terhadap keputusan penggunaan layanan taksi online akan membantu pelaku bisnis pada sektor ini untuk bertahan dan tumbuh di tengah persaingan yang semakin ketat.

\section{Tinjauan Pustaka}

\subsection{Harga}

Guna kesinambungan produksi setiap perusahaan selalu mengejar keuntungan. Keuntungan yang diperoleh ditentukan pada penetapan harga yang ditawarkan. Harga suatu produk ditentukan dari pengorbanan yang dilakukan untuk menghasilkan jasa dan laba atau keuntungan yang diharapkan. Oleh karena itu penentuan harga produk dari suatu perusahaan merupakan masalah yang cukup penting (Ii, 2015). Berikut ini merupakan beberapa pengertian harga menurut beberapa ahli:

Kotler \& Amstrong (2016:324) mendefinisikan bahwa: "Harga jumlah uang yang dibebankan untuk suatu produk atau layanan, atau jumlah nilai yang ditukar pelanggan dengan manfaat atau memiliki atau menggunakan produk atau layanan." Fandy Tjiptono (2016: 218) menyebutkan bahwa harga merupakan satu-satunya unsur bauran pemasaran yang mendatangkan pemasukan 
atau pendapatan bagi perusahaan. Menurut Suparyanto dan Rosad (2015:141), harga adalah jumlah sesuatu yang memiliki nilai pada umumnya berupa uang yang harus dikorbankan untuk mendaptkan suatu produk. Dari pengertian-pengertian di atas, dapat disimpulkan bahwa penetapan harga merupakan keputusan kritis yang menunjang keberhasilan suatu perusahaan.

Dimensi dan indikator persepsi harga menurut menurut Zeithmall (Ekonomika \& Semarang, 2018) adalah:

1. Dimensi Price Acceptance (Penerimaan Harga) dengan indikator harga produk dapat diterima oleh akal sehat dan memilih harga yang lebih murah.

2. Dimensi Price Evaluation (Evaluasi Harga) dengan indikator membandingkan harga dengan berbagai merek yang dipasarkan dan membandingkan harga dengan pembelian sebelum-nya.

3. Dimensi Perceived Worth (Nilai Yang Diterima) dengan indikator harga sesuai kualitas.

\subsection{Inovasi Layanan}

Menurut Niosi (Dewanto et all 2015: 42), inovasi didefinisikan sebagai produk atau proses baru yang lebih baik dari sebelumnya, suatu bentuk organisasi yang baru, penerapan teknologi yang ada untuk bidang baru, penemuan sumber daya baru, dan pembukaan pasar baru. Dengan demikian bahwa proses pengembangan bisnis, dan membantu perusahaan beradaptasi dan tumbuh di pasar dengan produk atau proses yang lebih baik dari sebelumnya merupakan inovasi (Maroun et al., 2016).

Menurut Kotler dalam (Moh Alifuddin \& Mashur Razak 2015:121) mendefiniskan inovasi sebagai suatu yang berkenaan dengan barang, jasa atau ide yang dirasakan baru oleh seseorang. Ide tersebut telah lama eksis tetapi ini dapat dikatakan suatu inovasi bagi orang yang baru melihat atau merasakannya. Perusahaan melakukan pengembangan menciptakan nilai dari aset perusahaan dengan mendesain ulang atau meningkatkan produk, layanan, atau metode dengan cara yang inovatif untuk menciptakan dan mempertahankan keunggulan kompetitifnya dengan mengintegrasikan sumber daya perusahaan. Inovasi layanan mendorong perusahaan untuk mengubah perubahan lingkungan menjadi peluang (Yulianto \& Hasan, 2019). Dari pengertian diatas dapat diketahui bahwa inovasi layanan adalah kegiatan pembaharuan yang dilakukan perusahaan untuk meningkatkan layanan serta mengahasilkan layanan baru.

Dimensi yang digunakan dalam penelitian ini adalah dimensi yang dikemukakan menurut (Muslichati, 2015):

1. Mengembangkan Model Bisnis Baru.

Mengembangkan model bisnis baru melibatkan perubahan mendasar dalam cara pendapatan dan keuntungan yang diperoleh. Inovasi dalam model bisnis dapat terjadi melalui integrasi bidang bisnis dalam satu proses, misalnya mendapatkan data basis pelanggan yang lebih luas dan menciptakan nilai lebih kepada pelanggan.

2. Mengembangkan Layanan Baru.

Pengembangan layanan baru dapat terjadi dalam banyak cara, yaitu dalam bentuk jasa atau konsep-konsep baru. Bentuk jasa baru akan mempengaruhi kinerja pemasaran karena apabila pengembangan layanan berhasil diterapkan maka akan meningkatkan kinerja pemasaran perusahaan, begitu juga sebaliknya apabila pengembangan layanan 
tersebut tidak berhasil dalam penerapannya kinerja pemasaran perusahaan akan mengalami penurunan.

3. Membuat interaksi dengan pelanggan baru.

Interaksi penyedia jasa dengan pelanggan memiliki hubungan yang sangat erat, interaksi ini membuat kedekatan antara konsumen dengan perusahaan sehingga perusahaan akan mudah mengetahui keinginan dan kebutuhan dari konsumen.

\subsection{Keputusan Penggunaan Jasa}

Keputusan penggunaan jasa atau lebih dikenal sebagai keputusan pembelian. Suatu proses pengambilan keputusan akan pembelian yang mencakup penentuan apa yang akan dibeli atau tidak melakukan pembelian dan keputusan itu diperoleh dari pengalaman-pengalaman sebelumnya merupakan keputusan pembelian. Menurut Kotler (Setiadi, 2015: 14 ) untuk sampai kepada keputusan pembelian konsumen akan melewati 5 tahap yaitu pengenalan masalah, pencarian informasi, evaluasi alternatif, keputusan pembelian dan perilaku setelah pembelian (Maroun et al., 2016).

Menurut Kotler dan Keller (2016:179) menyatakan bahwa perilaku konsumen adalah studi tentang bagaimana individu, kelompok, dan organisasi memilih, membeli, menggunakan dan bagaimana barang, jasa, ide atau pengalaman untuk memuaskan kebutuhan dan keinginan mereka.

Berdasarkan definisi diatas dapat diketahui bahwa perilaku konsumen merupakan suatu tindakan individu atau kelompok dalam menggunakan barang atau jasa sebagai proses pengambilan keputusan. Perilaku konsumen akan menentukan proses pengambilan keputusan dalam pembelian, proses tersebut merupakan sebuah pendekatan penyesuaian masalah yang terdiri dari lima tahap yang dilakukan konsumen, kelima tahap tersebut adalah pengenalan masalah, pencarian informasi, penilaian altematif, membuat keputusan, dan perilaku pasca pembelian. (- \& Anggriani, 2015).

Keputusan penggunaan jasa atau lebih dikenal dengan keputusan pembelian merupakan bagian dari perilaku konsumen. Pada dasarnya keputusan pembelian ialah suatu tindakan atau perilaku konsumen jadi atau tidaknya melakukan suatu pembelian atau transaksi, banyak tidaknya. (Trisnowati \& Nugraha, 2016). Menurut Kamus Besar Bahasa Indonesia, keputusan adalah sesuatu yang berkaitan dengan putusan, segala sesuatu yang telah ditetapkan. Menurut Romdonah (2015:2), keputusan pembelian merupakan suatu proses pengambilan keputusan akan pembelian yang mencakup penentuan apa yang akan dibeli atau tidak melakukan pembelian dan keputusan itu diperoleh oleh kegiatan-kegiatan sebelumnya.

Menurut Kotler \& Armstrong (2016:177) mendefinisikan keputusan pembelian sebagai berikut: "Consumer behavior is the study of how individual, groups, and organizations select, buy, use, and dispose of goods, services, ideas, or experiences to satisfy their needs and wants", yang artinya Keputusan pembelian merupakan bagian dari perilaku konsumen perilaku konsumen yaitu studi tentang bagaimana individu, kelompok, dan organisasi memilih, membeli, menggunakan, dan bagaimana barang, jasa, ide atau pengalaman untuk memuaskan kebutuhan dan keinginan mereka. Keputusan pembelian tidak terpisahkan dari bagaimana sifat seorang konsumen (consumer behavior) sehingga masing-masing konsumen memiliki kebiasaan yang berbeda dalam melakukan pembelian. Dari definisi diatas maka dapat dipahami bahwa keputusan pembelian merupakan sebuah tindakan yang dilakukan konsumen untuk membeli suatu produk. 
Adapun dimensi dan indikator dalam keputusan pembelian yang dijadikan acuan dalam penelitian menurut Kotler dan Keller (2016:188) dalam (Armahadyani, 2018) menjelaskan bahwa keputusan konsumen untuk melakukan pembelian suatu produk meliputi enam dimensi keputusan sebagai berikut:

1. Pilihan Produk.

Konsumen dapat mengambil keputusan untuk membeli sebuah produk atau menggunakan uangnya untuk tujuan lain. Dalam hal ini perusahaan harus memusatkan perhatiannya kepada orang-orang yang berminat membeli sebuah produk serta alternatif yang mereka pertimbangkan.

2. Pilihan Merek.

Pembeli harus mengambil keputusan tentang merek mana yang akan dibeli. Setiap merek memiliki perbedaan-perbedaan tersendiri. Dalam hal ini perusahaan harus mengetahui bagaimana konsumen memilih sebuah merek. Misalnya: kepercayaan dan popularitas merek.

3. Pilihan Penyalur.

Pembeli harus mengambil keputusan penyalur mana yang akan dikunjungi. Setiap pembeli mempunyai pertimbangan yang berbeda-beda dalam hal menentukan penyalur bisa dikarenakan faktor lokasi yang dekat, harga yang murah, persediaan barang yang lengkap dan lain-lain.

4. Waktu Pembelian.

Keputusan konsumen dalam pemilihan waktu pembelian bisa berbeda-beda, misalnya : ada yang membeli sebulan sekali, tiga bulan sekali, enam bulan sekali atau satu tahun sekali.

5. Jumlah Pembelian.

Konsumen dapat mengambil keputusan tentang seberapa banyak produk yang akan dibelinya pada suatu saat. Pembelian yang dilakukan mungkin lebih dari satu. Dalam hal ini perusahaan harus mempersiapkan banyaknya produk sesuai dengan keinginan yang berbeda-beda dari para pembeli.

6. Metode Pembayaran.

Konsumen dapat mengambil keputusan tentang metode pembayaran yang akan dilakukan dalam pengambilan keputusan menggunakan produk atau jasa. Saat ini keputusan pembelian dipengaruhi tidak hanya oleh aspek lingkungan dan keluarga, tetapi keputusan pembelian juga dipengaruhi oleh teknologi yang digunakan dalam transaksi pembelian.

\subsection{Hipotesis}

Berdasarkan kerangka pemikiran diatas, hipotesis ini ditetapkan sebagai berikut yang mana terdapat pengaruh positif antara Harga, Inovasi Layanan Aplikasi dan Keputusan Penggunaan Jasa pada Taksi Express yang bias diuraikan sebagai berikut:

Hal : Terdapat pengaruh yang signifikan antara variabel harga dengan keputusan penggunaan jasa taksi Express 
Ha2 : Terdapat pengaruh yang signifikan antara variabel Inovasi Pelayanan Aplikasi dengan keputusan penggunaan jasa taksi Express

Ha3 : Terdapat pengaruh yang signifikan antara variabel Harga dan Inovasi Pelayanan Aplikasi dengan keputusan penggunaan jasa taksi Express

\section{Metodologi}

\subsection{Populasi dan Sampel}

Responden yang dipilih oleh penulis dalam penelitian ini adalah Pengunduh Aplikasi Express Taxis yang pernah menggunakan jasa Taksi Express yang diperkirakan sebanyak 500 pengunduh. Karena populasi yang mana dalam penelitian ini cukup banyak, maka diambil beberapa sampel untuk mewakili populasi tersebut. Untuk menentukan jumlah sampel dari populasi pada penelitian ini yaitu dengan menggunakan rumus Isaac dan Michael. Rumus Isaac dan Michael ini telah diberikan hasil perhitungan yang berguna untuk menentukan jumlah sampel berdasarkan tingkat kesalahan 1\%, 5\%, dan 10\%. Pada penelitian ini tingkat kesalahan atau sampling error dalam menentukan jumlah sampel yaitu pada tingkat kesalahan $10 \%$. Adapun jumlah sampel dalam penelitian ini berjumlah 176. Dalam pengambilan sampel, peneliti menggunakan teknik non-probability sampling dengan teknik sampling purposive.

Peneliti melakukan pengumpulan data dengan melakukan penyebaran kuesioner dengan menggunakan skala. Skala yang digunakan dalam pengumpulan data penelitian ini adalah skala Likert, yakni skala untuk mengukur sikap, persepsi, dan pendapat seseorang tentang fenomena sosial. Setiap pernyataan diberi alternatif skor untuk mempermudah dalam mengolah data dari responden, berikut ini kriteria skor yang ditentukan oleh peneliti :

1. Untuk jawaban "Sangat Setuju (SS)" diberi skor 5.

2. Untuk jawaban "Setuju (S)" diberi skor 4.

3. Untuk jawaban "Cukup Setuju (CS)" diberi skor 3.

4. Untuk jawaban “Tidak Setuju (TS)" diberi skor 2.

5. Untuk jawaban "Sangat Tidak Setuju (STS)" diberi skor 1.

\subsection{Teknik Analisis Data}

Penelitian ini menganalisis data menggunakan Partial Least Square (PLS) dengan aplikasi SmartPLS. Dalam metode PLS, analisis data melalui beberapa tahap sebagai berikut:

\subsubsection{Analisa outer model}

Analisa outer model dilakukan untuk memastikan bahwa measurement yang digunakan layak untuk dijadikan pengukuran (valid dan reliabel) (Kusumawati, 2018). Dalam analisa model ini menspesifikasikan hubungan antar variabel laten dengan indikator-indikatornya. Analisa outer model dapat dilihat dari beberapa indikator:

a. Convergent Validity adalah indikator yang dinilai berdasarkan korelasi antara item score/component score dengan construct score, yang dapat dilihat dari standardized loading factor yang mana menggambarkan besarnya korelasi antar setiap item pengukuran (indikator) dengan konstraknya. Ukuran refleksif individual dikatakan tinggi jika berkorelasi $>0.7$ dengan konstruk yang ingin diukur, sedangkan menurut 
Chin yang dikutip oleh Imam Ghozali, nilai outer loading antara 0,5 - 0,6 sudah dianggap cukup.

b. Discriminant Validity merupakan model pengukuran dengan refleksif indicator dinilai berdasarkan crossloading pengukuran dengan konstruk. Jika korelasi konstruk dengan item pengukuran lebih besar daripada ukuran konstruk lainnya, maka menunjukan ukuran blok mereka lebih baik dibandingkan dengan blok lainnya. Sedangkan menurut metode lain untuk menilai discriminant validity yaitu dengan membandingkan nilai squareroot of average variance extracted (AVE).

c. Composite reliability merupakan indikator untuk mengukur suatu konstruk yang dapat dilihat pada view latent variable coefficients. Untuk mengevaluasi composite reliability terdapat dua alat ukur yaitu internal consistency dan cronbach's alpha. Dalam pengukuran tersebut apabila nilai yang dicapai adalah $>0,70$ maka dapat dikatakan bahwa konstruk tersebut memiliki reliabilitas yang tinggi.

d. Cronbach's Alpha merupakan uji reliabilitas yang dilakukan memperkuat hasil dari composite reliability. Suatu variabel dapat dinyatakan reliabel apabila memiliki nilai cronbach's alpha $>0,7.25$ Uji yang dilakukan diatas merupakan uji pada outer model untuk indikator reflektif. Untuk indikator formatif dilakukan pengujian yang berbeda. Uji untuk indikator formatif yaitu:

a. Significance of weights. Nilai weight indikator formatif dengan konstruknya harus signifikan.

b. Multicollinearity. Uji multicollinearity dilakukan untuk mengetahui hubungan antar indikator. Untuk mengetahui apakah indikator formatif mengalami multicollinearity dengan mengetahui nilai VIF. Nilai VIF antara 5-10 dapat dikatakan bahwa indikator tersebut terjadi multicollinearity.

\subsubsection{Analisa Inner Model}

Analisa Inner model biasanya juga disebut dengan (inner relation, structural model dan substantive theory) yang mana menggambarkan hubungan antara variabel laten berdasarkan pada substantive theory. Signifikansi hubungan antara konstrak dapat dilihat dari koefisien jalur (path coefficient) yang menggambarkan kekuatan hubungan antar konstrak. Tanda dalam path coefficient harus sesuai dengan teori yang dihipotesiskan, untuk menilai signifikansi path coefficient dapat dilihat dari t test (critical ratio) yang diperoleh dari proses bootstrapping (resampling method). Analisa inner model dapat dievaluasi yaitu dengan menggunakan Rsquare untuk konstruk dependen, Stone-Geisser Qsquare test untuk predictive relevance dan uji t serta signifikansi dari koefisien parameter jalur struktural. Dalam pengevaluasian inner model dengan PLS (Partial Least Square) dimulai dengan cara melihat Rsquare untuk setiap variabel laten dependen. Kemudian dalam penginterpretasiannya sama dengan interpretasi pada regresi. Perubahan nilai pada R-square dapat digunakan untuk menilai pengaruh variabel laten independen tertentu terhadap variabel laten dependen apakah memiliki pengaruh yang substantif (Kusumawati, 2018).

\section{Hasil Dan Diskusi}

\subsection{Analisis Deskriptif Responden}

Seperti pada Gambar 01, total responden berjumlah 176 orang, di mana sebanyak 53 orang pria dan 123 orang wanita. Dari faktor usia, responden yang berusia 16-19 tahun sebanyak 21 orang, 
usia 20-25 tahun sebanyak 151 orang, dan usia 26-35 tahun sebanyak 4 orang. Dari faktor pendidikan, responden yang berpendidikan terakhir SMP sebanyak 1 orang, SMA/SMK sebanyak 121 orang, dan D3/S1 sebanyak 54 orang. Dari faktor jenis pekerjaan, sebanyak 126 orang masih Pelajar/Mahasiswa, Pegawai Swasta sebanyak 24 orang, PNS sebanyak 2 orang, Wiraswasta sebanyak 7 orang, dan lain-lain sebanyak 17 orang. Dari sisi penghasilan, sebanyak 82 orang berpenghasilan $<$ Rp. 500.000, Rp. 500.000-2.000.000 sebanyak 44 orang, Rp. 2.000.000-3.500.000 sebanyak 13 orang, Rp. 3.500.000-5.000.000 sebanyak 18 orang dan $>$ Rp. 5.000.000 sebanyak 19 0rang.

\subsection{Analisis Model}

Hasil dari outer loading dan $\mathrm{t}$ statistik dari hasil output SmartPLS menunjukkan factor loading yang kurang dari 0,7 yaitu dari 27 item pertanyaan terdapat 4 item pertanyaan yang kurang dari 0,7 . Dengan demikian, terdapat 23 item pertanyaan yang dapat dikatakan valid (memiliki validitas yang signifikan).

Gambar 1. Analisis Deskriptif Responden

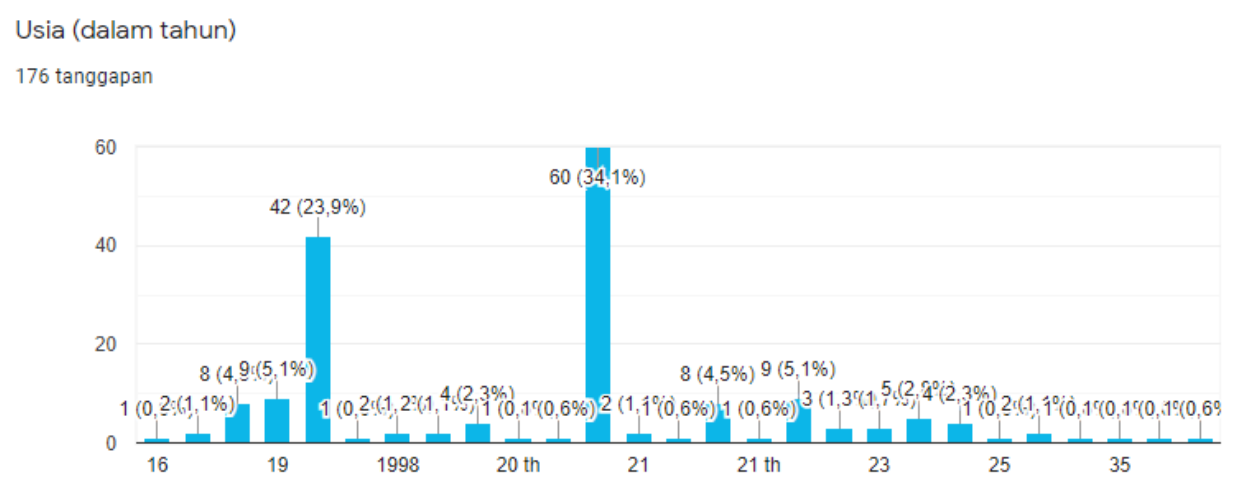

Jenis Kelamin

176 tanggapan
Pendidikan Terakhir

176 tanggapan
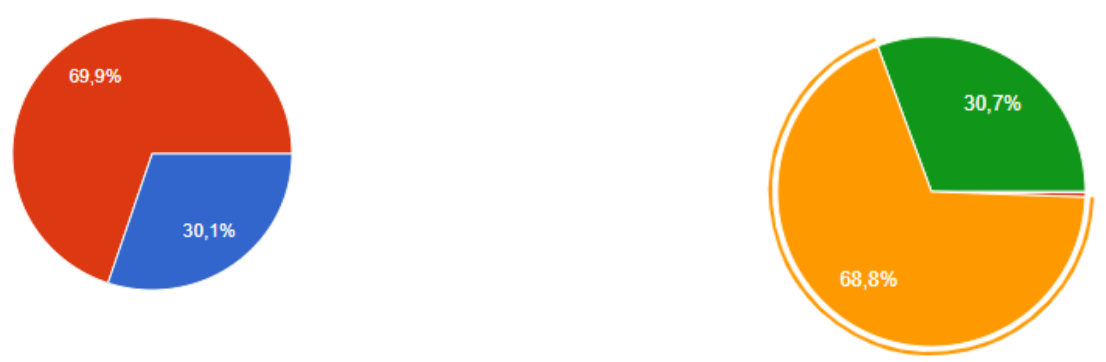

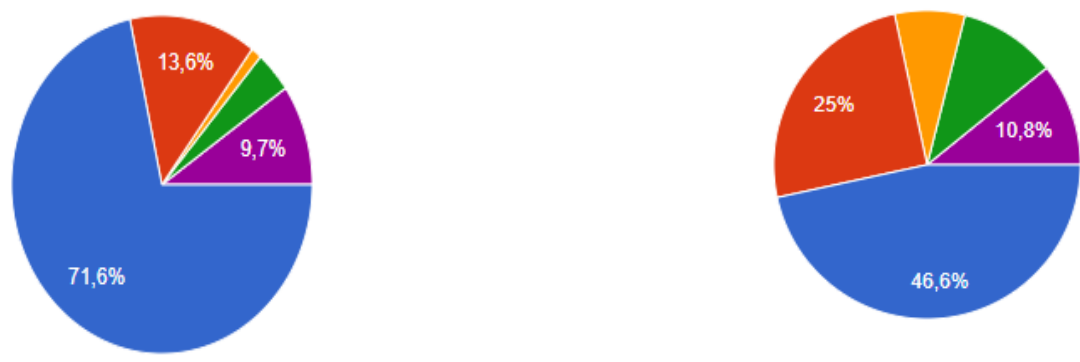

Tabel 3. Outer loadings (Mean, STDEV, T-Values)

\begin{tabular}{|c|c|c|c|c|c|}
\hline & $\begin{array}{c}\text { Original } \\
\text { Sample } \\
\text { (O) }\end{array}$ & $\begin{array}{l}\text { Sample } \\
\text { Mean } \\
\text { (M) }\end{array}$ & $\begin{array}{l}\text { Standard } \\
\text { Deviation } \\
\text { (STDEV) }\end{array}$ & $\begin{array}{l}\text { T Statistics } \\
(|\mathrm{O} / \mathrm{STDEV}|)\end{array}$ & $\begin{array}{c}\mathrm{P} \\
\text { Values }\end{array}$ \\
\hline X1.1<- Harga $(X 1)$ & 0.674 & 0.672 & 0.082 & 8.263 & 0.000 \\
\hline $\mathrm{X} 1.2<-\operatorname{Harga}(\mathrm{X} 1)$ & 0.821 & 0.817 & 0.040 & 20.751 & 0.000 \\
\hline X1.3<- Harga $(X 1)$ & 0.779 & 0.776 & 0.037 & 20.929 & 0.000 \\
\hline X1.4<- Harga (X1) & 0.746 & 0.747 & 0.040 & 18.719 & 0.000 \\
\hline $\mathrm{X} 1.5<-$ Harga $(\mathrm{X} 1)$ & 0.782 & 0.778 & 0.048 & 16.375 & 0.000 \\
\hline X1.6<- Harga $(X 1)$ & 0.681 & 0.681 & 0.049 & 13.878 & 0.000 \\
\hline X1.7<- Harga (X1) & 0.817 & 0.819 & 0.027 & 30.268 & 0.000 \\
\hline X1.8<- Harga $(X 1)$ & 0.844 & 0.846 & 0.021 & 40.416 & 0.000 \\
\hline X1.9<- Harga (X1) & 0.867 & 0.869 & 0.020 & 44.053 & 0.000 \\
\hline $\begin{array}{c}\text { X2.1 <- Inovasi Layanan } \\
\text { Aplikasi (X2) }\end{array}$ & 0.691 & 0.685 & 0.052 & 13.406 & 0.000 \\
\hline $\begin{array}{c}\text { X2.2 <- Inovasi Layanan } \\
\text { Aplikasi (X2) }\end{array}$ & 0.775 & 0.770 & 0.045 & 17.116 & 0.000 \\
\hline $\begin{array}{c}\text { X2.3 <- Inovasi Layanan } \\
\text { Aplikasi (X2) }\end{array}$ & 0.806 & 0.802 & 0.033 & 24.420 & 0.000 \\
\hline X2.4<- Inovasi Layanan & 0.741 & 0.738 & 0.046 & 16.175 & 0.000 \\
\hline
\end{tabular}




\begin{tabular}{|c|c|c|c|c|c|}
\hline Aplikasi (X2) & & & & & \\
\hline $\begin{array}{c}\text { X2.5 <- Inovasi Layanan } \\
\text { Aplikasi (X2) }\end{array}$ & 0.807 & 0.806 & 0.030 & 26.608 & 0.000 \\
\hline $\begin{array}{c}\text { X2.6 <- Inovasi Layanan } \\
\text { Aplikasi (X2) }\end{array}$ & 0.780 & 0.779 & 0.033 & 23.466 & 0.000 \\
\hline $\begin{array}{c}\text { X2.7 <- Inovasi Layanan } \\
\text { Aplikasi (X2) }\end{array}$ & 0.794 & 0.792 & 0.035 & 22.794 & 0.000 \\
\hline $\begin{array}{c}\text { X2.8 }<\text { - Inovasi Layanan } \\
\text { Aplikasi }(\mathrm{X} 2)\end{array}$ & 0.778 & 0.776 & 0.064 & 12.088 & 0.000 \\
\hline $\begin{array}{c}\text { X2.9 }<\text { - Inovasi Layanan } \\
\text { Aplikasi (X2) }\end{array}$ & 0.746 & 0.742 & 0.046 & 16.148 & 0.000 \\
\hline $\begin{array}{c}\text { Y.1 <- Keputusan Penggunaan } \\
\text { Jasa (Y) }\end{array}$ & 0.622 & 0.620 & 0.070 & 8.889 & 0.000 \\
\hline $\begin{array}{c}\text { Y.2 <- Keputusan Penggunaan } \\
\text { Jasa (Y) }\end{array}$ & 0.763 & 0.762 & 0.042 & 18.157 & 0.000 \\
\hline $\begin{array}{c}\text { Y.3 <- Keputusan Penggunaan } \\
\text { Jasa (Y) }\end{array}$ & 0.731 & 0.729 & 0.048 & 15.114 & 0.000 \\
\hline $\begin{array}{c}\text { Y.4 <- Keputusan Penggunaan } \\
\text { Jasa (Y) }\end{array}$ & 0.780 & 0.779 & 0.038 & 20.482 & 0.000 \\
\hline $\begin{array}{c}\text { Y.5 <- Keputusan Penggunaan } \\
\text { Jasa (Y) }\end{array}$ & 0.775 & 0.773 & 0.044 & 17.465 & 0.000 \\
\hline $\begin{array}{c}\text { Y.6 <- Keputusan Penggunaan } \\
\text { Jasa (Y) }\end{array}$ & 0.875 & 0.876 & 0.016 & 54.081 & 0.000 \\
\hline $\begin{array}{c}\text { Y.7 <- Keputusan Penggunaan } \\
\text { Jasa (Y) }\end{array}$ & 0.719 & 0.721 & 0.056 & 12.874 & 0.000 \\
\hline $\begin{array}{c}\text { Y.8 <- Keputusan Penggunaan } \\
\text { Jasa (Y) }\end{array}$ & 0.754 & 0.757 & 0.042 & 18.089 & 0.000 \\
\hline $\begin{array}{c}\text { Y.9<- Keputusan Penggunaan } \\
\text { Jasa }(Y)\end{array}$ & 0.787 & 0.787 & 0.031 & 25.642 & 0.000 \\
\hline
\end{tabular}

Dari hasil uji olah data menggunakan SmartyPLS dapat ditemukan cronbach's alpha sebagai berikut: 
Tabel 4. Cronbach's Alpha

\begin{tabular}{|c|c|}
\hline & Cronbach's Alpha \\
\hline Harga (X1) & 0.919 \\
\hline Inovasi Layanan Aplikasi (X2) & 0.914 \\
\hline Keputusan Penggunaan Jasa (Y) & 0.907 \\
\hline
\end{tabular}

Hasil Cronbach's Alpha pada tabel 4. memperlihatkan semua variabel mempunyai nilai Cronbachs Alpha diatas 0,7. Variabel Harga (X1) dengan nilai 0.919, Inovasi Layanan Aplikasi (X2) dengan nilai 0.914, Keputusan Penggunaan Jasa (Y) dengan nilai 0.907. Dengan demikian kreteria dikatakan reliable.

Untuk mengevaluasi validitas diskriminan dapat dilihat dengan metode average variance extracted (AVE) untuk setiap konstruk atau variabel laten. Model memiliki validitas diskriminan yang lebih baik apabila akar kuadrat AVE untuk masing-masing konstruk lebuh besar dari korelasi antara dua konstruk di dalam model. Dalam penelitian ini, nilai AVE dan akar kuadrat AVE untuk masing-masing konstruk disajikan pada Tabel 4.12

Tabel 5. Cronbach's Alpha

\begin{tabular}{|c|c|}
\hline & Average Variance Extracted (AVE) \\
\hline Harga (X1) & 0.611 \\
\hline Inovasi Layanan Aplikasi (X2) & 0.592 \\
\hline Keputusan Penggunaan Jasa (Y) & 0.576 \\
\hline
\end{tabular}

Output AVE seperti yang terlihat pada tabel 4.12, semuanya menunjukkan nilai di atas 0,50. Variabel Harga (X1) dengan nilai output AVE sebesar 0.611, Inovasi Layanan Aplikasi dengan nilai AVE 0.592 dan Keputusan Penggunaan Jasa dengan nilai AVE 0.576. Dengan demikian dapat dikatakan convergent validity yang baik.

Validitas diskriminan digunakan untuk memastikan bahwa setiap konsep dari masing-masing konstruk atau variabel laten berbeda dengan variabel lainnya. Tabel dibawah ini menunjukkan hasil validitas diskriminan dari model penelitian dengan melihat cross loading-nya.

Tabel 6. Nilai discriminant validity X1 (harga)

\begin{tabular}{|c|c|c|c|}
\hline & Harga (X1) & $\begin{array}{c}\text { Inovasi Layanan } \\
\text { Aplikasi (X2) }\end{array}$ & $\begin{array}{c}\text { Keputusan Penggunaan } \\
\text { Jasa (Y) }\end{array}$ \\
\hline $\mathrm{X} 1.1$ & 0.674 & 0.411 & 0.412 \\
\hline $\mathrm{X} 1.2$ & 0.821 & 0.487 & 0.421 \\
\hline $\mathrm{X} 1.3$ & 0.779 & 0.446 & 0.392 \\
\hline
\end{tabular}




\begin{tabular}{|c|c|c|c|}
\hline X1.4 & 0.746 & 0.636 & 0.415 \\
\hline X1.5 & 0.782 & 0.546 & 0.350 \\
\hline X1.6 & 0.681 & 0.608 & 0.388 \\
\hline X1.7 & 0.817 & 0.585 & 0.508 \\
\hline X1.8 & 0.844 & 0.543 & 0.454 \\
\hline X1.9 & 0.867 & 0.573 & 0.496 \\
\hline X2.1 & 0.531 & 0.691 & 0.352 \\
\hline X2.2 & 0.572 & 0.775 & 0.436 \\
\hline X2.3 & 0.571 & 0.806 & 0.432 \\
\hline$X 2.4$ & 0.454 & 0.741 & 0.514 \\
\hline X2.5 & 0.542 & 0.807 & 0.575 \\
\hline X2.6 & 0.509 & 0.780 & 0.561 \\
\hline$X 2.7$ & 0.555 & 0.794 & 0.550 \\
\hline $\mathrm{X} 2.8$ & 0.558 & 0.778 & 0.474 \\
\hline X2.9 & 0.526 & 0.746 & 0.527 \\
\hline Y.1 & 0.265 & 0.349 & 0.622 \\
\hline Y.2 & 0.383 & 0.446 & 0.763 \\
\hline Y.3 & 0.428 & 0.463 & 0.731 \\
\hline Y.4 & 0.368 & 0.456 & 0.780 \\
\hline Y.5 & 0.313 & 0.482 & 0.775 \\
\hline Y.6 & 0.543 & 0.614 & 0.875 \\
\hline Y.7 & 0.319 & 0.463 & 0.719 \\
\hline Y.8 & 0.617 & 0.518 & 0.754 \\
\hline Y.9 & 0.408 & 0.536 & 0.787 \\
\hline
\end{tabular}

Dari hasil cross loading pada Tabel 4.13 menunjukkan bahwa nilai korelasi konstrak X1 dengan 
indikatornya lebih besar daripada nilai korelasi dengan konstrak lainnya. Dengan demikian bahwa semua konstrak atau variabel laten sudah memiliki discriminant validity yang baik, dimana indikator pada blok indikator konstrak tersebut lebih baik daripada indikator di blok lainnya.

Tabel 7. Nilai discriminant validity X2 (inovasi layanan aplikasi)

\begin{tabular}{|c|c|c|c|}
\hline & Harga (X1) & $\begin{array}{l}\text { Inovasi Layanan } \\
\text { Aplikasi (X2) }\end{array}$ & $\begin{array}{c}\text { Keputusan Penggunaan } \\
\text { Jasa (Y) }\end{array}$ \\
\hline $\mathrm{X} 1.1$ & 0.674 & 0.411 & 0.412 \\
\hline $\mathrm{X} 1.2$ & 0.821 & 0.487 & 0.421 \\
\hline $\mathrm{X} 1.3$ & 0.779 & 0.446 & 0.392 \\
\hline $\mathrm{X} 1.4$ & 0.746 & 0.636 & 0.415 \\
\hline $\mathrm{X} 1.5$ & 0.782 & 0.546 & 0.350 \\
\hline X1.6 & 0.681 & 0.608 & 0.388 \\
\hline $\mathrm{X} 1.7$ & 0.817 & 0.585 & 0.508 \\
\hline $\mathrm{X} 1.8$ & 0.844 & 0.543 & 0.454 \\
\hline X1.9 & 0.867 & 0.573 & 0.496 \\
\hline $\mathrm{X} 2.1$ & 0.531 & 0.691 & 0.352 \\
\hline $\mathrm{X} 2.2$ & 0.572 & 0.775 & 0.436 \\
\hline $\mathrm{X} 2.3$ & 0.571 & 0.806 & 0.432 \\
\hline $\mathrm{X} 2.4$ & 0.454 & 0.741 & 0.514 \\
\hline $\mathrm{X} 2.5$ & 0.542 & 0.807 & 0.575 \\
\hline $\mathrm{X} 2.6$ & 0.509 & 0.780 & 0.561 \\
\hline $\mathrm{X} 2.7$ & 0.555 & 0.794 & 0.550 \\
\hline $\mathrm{X} 2.8$ & 0.558 & 0.778 & 0.474 \\
\hline $\mathrm{X} 2.9$ & 0.526 & 0.746 & 0.527 \\
\hline Y.1 & 0.265 & 0.349 & 0.622 \\
\hline Y.2 & 0.383 & 0.446 & 0.763 \\
\hline
\end{tabular}




\begin{tabular}{|c|c|c|c|}
\hline Y.3 & 0.428 & 0.463 & 0.731 \\
\hline Y.4 & 0.368 & 0.456 & 0.780 \\
\hline Y.5 & 0.313 & 0.482 & 0.775 \\
\hline Y.6 & 0.543 & 0.614 & 0.875 \\
\hline Y.7 & 0.319 & 0.463 & 0.719 \\
\hline Y.8 & 0.617 & 0.518 & 0.754 \\
\hline Y.9 & 0.408 & 0.536 & 0.787 \\
\hline
\end{tabular}

Dari hasil cross loading pada Tabel 4. menunjukkan bahwa nilai korelasi konstrak X2 dengan indikatornya lebih besar daripada nilai korelasi dengan konstrak lainnya. Dengan demikian bahwa semua konstrak atau variabel laten sudah memiliki discriminant validity yang baik, dimana indikator pada blok indikator konstrak tersebut lebih baik daripada indikator di blok lainnya.

Tabel 8. Nilai discriminant validity X2 (inovasi layanan aplikasi)

\begin{tabular}{|c|c|c|c|}
\hline & Harga (X1) & $\begin{array}{c}\text { Inovasi Layanan } \\
\text { Aplikasi (X2) }\end{array}$ & $\begin{array}{c}\text { Keputusan Penggunaan } \\
\text { Jasa (Y) }\end{array}$ \\
\hline X1.1 & 0.674 & 0.411 & 0.412 \\
\hline X1.2 & 0.821 & 0.487 & 0.421 \\
\hline X1.3 & 0.779 & 0.446 & 0.392 \\
\hline X1.4 & 0.746 & 0.636 & 0.415 \\
\hline X1.5 & 0.782 & 0.546 & 0.388 \\
\hline X1.6 & 0.681 & 0.608 & 0.508 \\
\hline X1.7 & 0.817 & 0.585 & 0.454 \\
\hline X1.8 & 0.844 & 0.543 & 0.496 \\
\hline X1.9 & 0.867 & 0.573 & 0.352 \\
\hline X2.1 & 0.531 & 0.691 & 0.436 \\
\hline X2.2 & 0.572 & 0.775 & 0.432 \\
\hline X2.3 & 0.571 & 0.806 & \\
\hline
\end{tabular}




\begin{tabular}{|c|c|c|c|}
\hline $\mathrm{X} 2.4$ & 0.454 & 0.741 & 0.514 \\
\hline $\mathrm{X} 2.5$ & 0.542 & 0.807 & 0.575 \\
\hline $\mathrm{X} 2.6$ & 0.509 & 0.780 & 0.561 \\
\hline $\mathrm{X} 2.7$ & 0.555 & 0.794 & 0.550 \\
\hline $\mathrm{X} 2.8$ & 0.558 & 0.778 & 0.474 \\
\hline X2.9 & 0.526 & 0.746 & 0.527 \\
\hline Y.1 & 0.265 & 0.349 & 0.622 \\
\hline Y.2 & 0.383 & 0.446 & 0.763 \\
\hline Y.3 & 0.428 & 0.463 & 0.731 \\
\hline Y.4 & 0.368 & 0.456 & 0.780 \\
\hline Y.5 & 0.313 & 0.482 & 0.775 \\
\hline Y.6 & 0.543 & 0.614 & 0.875 \\
\hline Y.7 & 0.319 & 0.463 & 0.719 \\
\hline Y.8 & 0.617 & 0.518 & 0.754 \\
\hline Y.9 & 0.408 & 0.536 & 0.787 \\
\hline
\end{tabular}

Dari hasil cross loading pada Tabel 4.15 menunjukkan bahwa nilai korelasi konstrak Y dengan indikatornya lebih besar daripada nilai korelasi dengan konstrak lainnya. Dengan demikian bahwa semua konstrak atau variabel laten sudah memiliki discriminant validity yang baik, dimana indikator pada blok indikator konstrak tersebut lebih baik daripada indikator di blok lainnya.

\subsection{Analisis Model Struktural}

Pengujian terhadap model struktural dengan cara melihat R-square, hasil output SmartPLS dengan menggunakan calculate-PLS Algorithm sebagai berikut:

Tabel 9. R-Square

\begin{tabular}{|c|c|c|}
\hline & R Square & $\begin{array}{c}\text { R Square } \\
\text { Adjusted }\end{array}$ \\
\hline Inovasi Layanan Aplikasi (X2) & 0.484 & 0.481 \\
\hline
\end{tabular}


Hasil R-Square pada tabel 4.16 pengaruh Harga (X1) terhadap Inovasi Layanan Aplikasi (X2) memberikan nilai sebesar 0,484, artinya variabel konstruk Inovasi Layanan Aplikasi (X2) yang dapat dijelaskan oleh variabel konstruk Harga sebesar 48,4\%, sedangkan sisanya 51,6\% dijelaskan oleh variabel lain diluar yang diteliti. Selanjutnya pengaruh variabel konstruk Harga (X1), variabel konstruk Inovasi Layanan Aplikasi (X2) terhadap variabel konstruk Keputusan Penggunaan Jasa (Y) memberikan nilai R-square sebesar 0.433 , artinya variabel konstruk Keputusan Penggunaan Jasa yang dapat dijelaskan oleh variabel konstruk Harga (X1), variabel konstruk Inovasi Layanan Aplikasi (X2) sebesar 43,3\%, sedangkan sisanya 56,7\% dijelaskan oleh variabel lain diluar yang diteliti.

Untuk melihat signifikansi pengaruh Harga, Inovasi Layanan Aplikasi Terhadap Keputusan PEnggunaan Jasa yaitu dengan melihat nilai koefisien parameter dan nilai signifikansi t statistic. Hasil output SmartPLS dengan menggunakan calculate-PLS Bootstrapping sebagai berikut:

Tabel 10. Path coeficients (Mean, STDEV, T-Values)

\begin{tabular}{|c|c|c|c|c|c|}
\hline & $\begin{array}{c}\text { Original } \\
\text { Sample (O) }\end{array}$ & $\begin{array}{c}\text { Sample } \\
\text { Mean (M) }\end{array}$ & $\begin{array}{c}\text { Standard } \\
\text { Deviation } \\
(\text { STDEV })\end{array}$ & $\begin{array}{c}\text { T Statistics } \\
(\mid \mathrm{O} / \text { STDEV } \mid)\end{array}$ & P Values \\
\hline $\begin{array}{c}\text { Harga (X1) -> } \\
\text { Keputusan } \\
\begin{array}{c}\text { Penggunaan Jasa } \\
\text { (Y) }\end{array}\end{array}$ & 0.198 & 0.205 & 0.100 & 1.979 & 0.048 \\
\hline $\begin{array}{c}\text { Inovasi Layanan } \\
\text { Aplikasi (X2) -> } \\
\text { Keputusan } \\
\begin{array}{c}\text { Penggunaan Jasa } \\
\text { (Y) }\end{array}\end{array}$ & 0.504 & 0.501 & 0.084 & 5.987 & 0.000 \\
\hline
\end{tabular}

Hasil Path Coefficients pada tabel 10. memperlihatkan Harga (X1) terhadap Inovasi Layanan Aplikasi (X2) menunjukkan nilai koefisien jalur sebesar 0,696 dan t statistic 13,943 lebih besar dari $\mathrm{t}$ tabel 1,6537 ( $\mathrm{t}$ statistic $>\mathrm{t}$ tabel), dengan demikian variabel harga berpengaruh positif dan signifikan terhadap variabel Inovasi Layanan Aplikasi (X2). Variabel Harga (X1) terhadap Keputusan Penggunaan Jasa (Y) menunjukkan nilai koefisien sebesar 0,198 dengan $t$ statistic 1,979 lebih besar dari $t$ tabel 1,6537 (t statistic $>t$ tabel), dengan demikian variabel Harga (X1) berpengaruh positif dan signifikan terhadap variabel Keputusan Penggunaan Jasa (Y). Variabel Inovasi Layanan Aplikasi (X2) terhadap Keputusan Penggunaan Jasa (Y) menunjukkan nilai koefisien sebesar 0,504 dengan $\mathrm{t}$ statistic 5,987 lebih besar dari $\mathrm{t}$ tabel 1,6537 ( $\mathrm{t}$ statistic $>\mathrm{t}$ tabel), dengan demikian variabel Harga (X1) berpengaruh positif dan signifikan terhadap variabel Keputusan Penggunaan Jasa (Y).

Untuk mengetahui pengaruh simultan atau pengaruh secara bersama-sama antara variabel X1 (Harga) dan variabel X2 (Inovasi Layanan Aplikasi) terhadap variabel Y (Keputusan Penggunaan Jasa) dapat dilakukan dengan menggunakan Uji F (Simultan). Uji statistik F dapat disebut juga tentang kebaikan model regresi (goodness of fit). Maksudnya, seberapa baik data 
sampel suatu penelitian fit dengan model regresi yang diajukan dalam penelitian tersebut. Untuk menguji kebenaran hipotesis 1 digunakan uji $\mathrm{F}$ dengan tingkat signifikansi $10 \%(\mathrm{a}=$ $0,1)$.

Gambar 2. Diagram Jalur

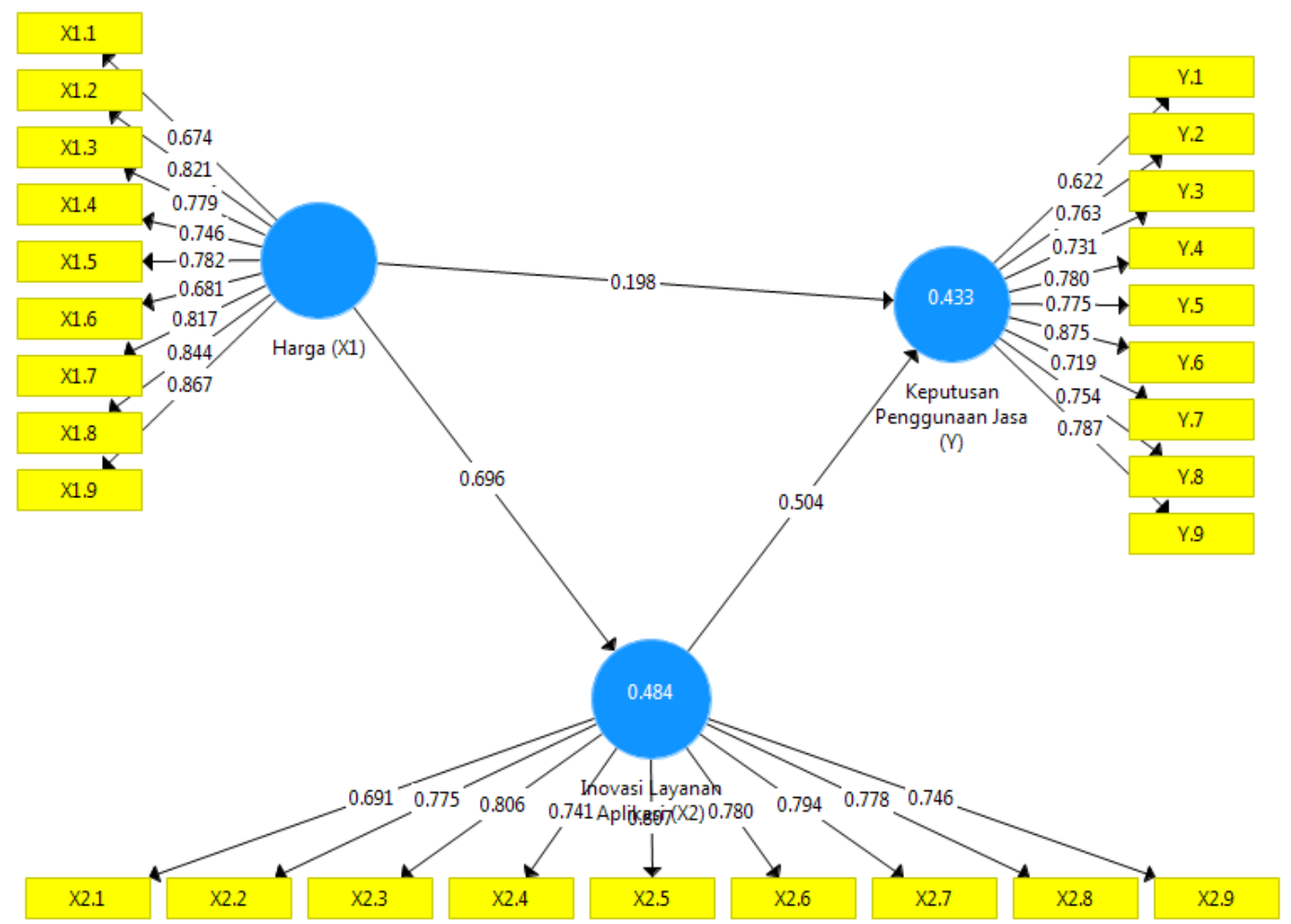

\subsection{Pengaruh X1 terhadap $Y$}

Berdasarkan hasil analisis data menggunakan SmartPLS seperti pada tabel 4.14 dimana Original Sample (O) merupakan koefisien jalur yaitu memperlihatkan Variabel Harga (X1) terhadap Keputusan Penggunaan Jasa (Y) menunjukkan nilai koefisien sebesar 0,198 dengan t statistic 1,979 lebih besar dari t tabel 1,6537 ( $\mathrm{t}$ statistic $>\mathrm{t}$ tabel), dengan demikian variabel Harga (X1) berpengaruh positif dan signifikan terhadap variabel Keputusan Penggunaan Jasa $(\mathrm{Y})$.

\subsection{Pengaruh X2 terhadap}

Berdasarkan hasil analisis data menggunakan SmartPLS seperti pada tabel 4.14 dimana Original Sample $(O)$ merupakan koefisien jalur yaitu memperlihatkan Variabel Inovasi Layanan Aplikasi (X2) terhadap Keputusan Penggunaan Jasa (Y) menunjukkan nilai koefisien sebesar 0,504 dengan $\mathrm{t}$ statistic 5,987 lebih besar dari t tabel 1,6537 (t statistic $>\mathrm{t}$ tabel), dengan demikian variabel Harga (X1) berpengaruh positif dan signifikan terhadap variabel Keputusan Penggunaan Jasa (Y).

\subsection{Pengaruh X1 dan X2 terhadap $Y$}

Berdasarkan hasil analisis data menggunakan SmartPL hasil R-Square pada tabel 4.14 pengaruh 
variabel konstruk Harga (X1), variabel konstruk Inovasi Layanan Aplikasi (X2) terhadap variabel konstruk Keputusan Penggunaan Jasa (Y) memberikan nilai R-square sebesar 0.433.

Berdasarkan hasil perhitungan diperoleh nilai $\mathrm{F}$ hitung sebesar 66,06. Dimana kriteria penolakan $\mathrm{H}_{0}$ jika $\mathrm{F}$ hitung lebih besar dari $\mathrm{F}$ tabel atau $\mathrm{F}_{0}>\mathrm{F}_{\alpha} 1$, n-3 dengan mengambil taraf signifikan $(\alpha)$ sebesar $10 \%$ maka dari tabel distribusi $\mathrm{F}$ didapat nilai $\mathrm{F}$ tabel untuk $\mathrm{F}_{0,10} 2173=$ 2,33 dikarenakan Fhitung lebih besar dari Ftabel dan sig $\mathrm{F}$ sebesar $\mathbf{0 , 0 0 0}$ maka $\mathrm{H}_{0}$ ditolak, artinya dapat disimpulkan bahwa terdapat hubungan secara simultan antara Harga dan Inovasi Layanan Aplikasi dengan Keputusan Penggunaan Jasa atau dapat diartikan bahwa terdapat pegaruh secara bersama-sama antara Harga dan Inovasi Layanan Aplikasi dengan Keputusan Penggunaan Jasa.

\section{Kesimpulan}

Berdasarkan hasil penelitian yang telah dilakukan menggunakan Partial Least Square (PLS) untuk mengukur pengaruh harga dan inovasi layanan terhadap keputusan penggunaan Express Taxis, maka dapat diambil kesimpulan sebagai berikut:

1. Terdapat pengaruh positif harga terhadap keputusan penggunaan jasa.

2. Terdapat pengaruh positif inovasi layanan aplikasi terhadap keputusan penggunaan jasa.

3. Terdapat pengaruh simultan yang positif antara harga dan inovasi layanan aplikasi terhadap keputusan penggunaan jasa.

Pemasaran dengan memanfaatkan internet memiliki banyak keunggulan dibandingkan dengan transaksi konvensional, terutama untuk pengusaha kecil menengah. Program digital marketing dapat meningkatkan volume penjualan karena dengan adanya pemasaran melalui internet dapat mempengaruhi keputusan pembelian. Perusahaan dengan transaksi konvensional dianjurkan untuk mengikuti tren dengan pemasaran melalui internet karena dengan digital marketing modal yang dikeluarkan lebih murah serta perusahaan dapat meningkatkan volume penjualan sehingga perusahaan akan mendapatkan laba yang lebih besar. Perusahaan harus mempunyai pengetahuan yang luas mengenai prilaku konsumen agar dapat memberikan definisi pasar yang baik untuk mengikuti perubahan yang konsisten dan terus menerus serta untuk merancang bauran pemasaran yang tepat.

PT Express Transindo Utama Tbk harus dapat selalu memanfaatkan kekuatan yang dimiliki untuk mengambil peluang-peluang yang bersifat strategis seperti meningkatkan jumlah kendaraan armada taksi, pengembangan teknologi dan kualitas pelayanan kepada pelanggan sehingga akan memperkuat posisinya di industri taksi di Jakarta dan Indonesia pada umumya.

\section{Referensi}

-, M., \& Anggriani, I. (2015). Hubungan Pelayanan Dengan Keputusan Menggunakan Jasa Pt. Anugrah Quba Mandiri Bengkulu. Ekombis Review, 3(2).

Armahadyani. (2018). Pelayanan Terhadap Keputusan Pembelian Konsumen Pada Kedai Makan Pa ’ Mur Karawang. Jurnal Manajemen \& Bisnis Kreatif, 03, Nomor.

Aslami, R. N., B A B, \& Penelitian, A. M. (2015). 37 | P a g e. 37-53.

Daft, richard 1. (2017). Management (Twelfth Ed).

DH, A. T. S. A. F., \& Sanawiri, B. (2018). Pengaruh Gaya Hidup Dan Inovasi Produk Terhadap Keputusan Pembelian (Survei Pada Mahasoswa S1 Jurusan Ilmu Administrasi Bisnis). 
Vol.62(No.1), 73-81.

Ekonomi, F., \& Manajemen, J. (2018). Pengaruh Kualitas Produk, Harga Dan Kualitas Pelayanan Terhadap Kepuasan Konsumen Pada Pt. Air Manado. Jurnal EMBA: Jurnal Riset Ekonomi, Manajemen, Bisnis Dan Akuntansi, 6(3), 1658-1667.

Ekonomika, F., \& Semarang, U. S. (2018). Hidup Dalam Mempengaruhi Proses Keputusan Pembelian Minuman Isotonik ( Studi Konsumen Minuman Isotonik Di Kota Semarang ). (2016), 978-979.

Elifele, F. (2018). Hasil dan pembahasan. (Guyton), 27-78.

Erwin, F. (2016). Direktorat Jendral Perhubungan Darat , “Masterplan Transportasi Darat ”, 2005 1. 1-13.

Fallis, A. . (2015). 済無No Title No Title. Journal of Chemical Information and Modeling, 53(9), 1689-1699. https://doi.org/10.1017/CBO9781107415324.004

Francisco, A. R. L. (2015). 済無No Title No Title. Journal of Chemical Information and Modeling, 53(9), 1689-1699. https://doi.org/10.1017/CBO9781107415324.004

Francisco, A. R. L. (2016). 済無No Title No Title. Journal of Chemical Information and Modeling, 53(9), 1689-1699. https://doi.org/10.1017/CBO9781107415324.004

goleman, daniel; boyatzis, Richard; Mckee, A. (2019). 済無No Title No Title. Journal of Chemical Information and Modeling, 53(9), 1689-1699. https://doi.org/10.1017/CBO9781107415324.004

Ii, B. A. B. (2015). No Title. 9-22.

Kusumawati, N. (2018). Metode Penelitian. Metode Penelitian, 81-92.

Lestari, P. (2017). Pengaruh Kualitas Produk Dan Harga Terhadap Kepuasan Konsumen Dan Dampaknya Terhadap Kepercayaan Konsumen Teh Botol Sosro. 22-70. Retrieved from http://repository.unpas.ac.id/30183/

Maroun, W., Joosub, T., Nakatani, Y., Ichikawa, K., Aptaguna, A., Pitaloka, E., ... Wacana, K. (2016a). 1.356<.1.984. Sedangkan Variabel inovasi layanan berpengaruh signifikan terhadap keputusan konsumen dengan t. Universitas Stuttgart, 3(3), 3. https://doi.org/10.1108/10309611211287297

Maroun, W., Joosub, T., Nakatani, Y., Ichikawa, K., Aptaguna, A., Pitaloka, E., ... Wacana, K. (2016b). Pengaruh Brand Image dan Inovasi Layanan Terhadap Keputusan Konsumen Menggunakan Go-Jek Di Kota Makassar. Universitas Stuttgart, 3(3), 3. https://doi.org/10.1108/10309611211287297

Marsada, V. (2014). Dampak Transportasi Online Terhadap Kesejahteraan Supir Taxi Blue Bird Di Kota Medan. Jurnal Manajemen, (X), 1-5. https://doi.org/10.1007/s13398-014-0173-7.2

Motors, G., \& Europe, W. (2016). Penerapan Strategi Pemasaran Jasa Transportasi Taksi Konvensional Blue BirdDalam Menghadapi Persaingan Jasa Transportasi Berbasis Aplikasi Online di Surabaya. (June), 1-11.

Muksin, D. R. M., \& Sunarti. (2018). Pengaruh Motivasi terhadap Keputusan Berkunjung Wisatawan di Ekowisata Mangrove Wonorejo Surabaya. Jurnal Administrasi Bisnis $(J A B) \mid$ Vol.55, 55(1), 196-203. 
Muslichati, E. L. A. Z. (2015). 7311411062-sTA.

Perdana. (2018). 済無No Title No Title. Journal of Chemical Information and Modeling, 53(9), 1689-1699. https://doi.org/10.1017/CBO9781107415324.004

Pustaka, K., Pemikiran, K., \& Hipotesis, D. A. N. (n.d.). No Title. 19-56.

Rizan, M., Fadillah, E., \& Kresnamurti R. P., A. (2015). Influence of Service Quality and Fare Toward Customer Satisfaction and Its Impact on Customer Loyalty of Express Taxi in Jakarta. JRMSI - Jurnal Riset Manajemen Sains Indonesia, 6(2), 618. https://doi.org/10.21009/jrmsi.006.2.07

Trisnowati, D. K., \& Nugraha, H. S. (2016). Pengaruh Harga Dan Kualitas Pelayanan Terhadap Keputusan Penggunaan Jasa Bengkel Pt . Astra International Tbk-Daihatsu. 1-8.

Yulianto, G., \& Hasan, A. (2019). 02 Pengaruh Orientasi Pasar, Konsumen, Merek, Dan Inovasi Layanan Terhadap Kinerja Umkm Di Yogyakarta. 17, 13. https://doi.org/10.31227/osf.io/vkndm 